\title{
Happy Birthday, You're Fired! The Effects of an Age-Dependent Minimum Wage on Youth Employment Flows in the Netherlands
}

\begin{abstract}
Jan Kabátek*
[[abstract]] The Dutch minimum wage for workers aged 15 to 23 is defined as a stepwise increasing function of a worker's calendar age. Using Dutch administrative records, the author shows that the birthday discontinuities of age-dependent minimum wage rates affect both labor market entry (job accessions) and labor market exit (job separations) of minimum wage workers. The job separations spike in the three months that precede workers' birthdays, suggesting that firms are dismissing workers whose costs are about to go up. The frequency of job accessions increases immediately after the birthdays and the increase is sustained throughout the following months. The resulting effect on employment levels is dynamic, with the employment rate being subject to an initial drop that is gradually compensated for by the higher rates of post-birthday labor market entry.
\end{abstract}

* Jan Kabátek is a Research Fellow at the Melbourne Institute: Applied Economic and Social Research and ARC Centre of Excellence for Children and Families over the Life Course, University of Melbourne; a Research Fellow at the Institute of Labor Economics (IZA); and an Extramural Fellow at CentER, Tilburg University, the Netherlands.

I gratefully acknowledge funding from the Australian Research Council Centre of Excellence for Children and Families over the Life Course. I have benefited from comments by Nicole Bosch, Richard Burkhauser, Deborah Cobb-Clark, Arindrajit Dube, David Neumark, Jan van Ours, Andreas Peichl, David Ribar, Yuri Rhodenborgh, Arthur van Soest, Jan Tilly, and seminar participants at DIW Berlin, Dutch Bureau of Policy Analysis, Dutch Ministry of Social Affairs and Employment, Goethe University Frankfurt, IAB Minimum Wage Conference, Tilburg University, University of Groningen, University of Sydney, and ZEW Mannheim. An Online Appendix is available at http://journals.sagepub.com/doi/suppl/DOI. This article draws on proprietary data provided by Statistics Netherlands. Researchers who obtain access to the data sets of Statistics Netherlands will be able to replicate all findings. Additional results and copies of the computer programs used to generate the results presented in the article are available from the author at j.kabatek@unimelb.edu.au.

Keywords: minimum wage, labor market flows, youth workers, age dependency, churning 
Many countries use age-dependent minimum wage systems to facilitate the entry of young workers into the labor force. An age-dependent system subjects young workers to a reduced minimum wage rate, which makes them more desirable for firms and therefore more likely to find a job that accommodates their lower levels of skills and experience. As workers age, they become eligible for higher minimum wage rates, eventually reaching the adult minimum wage level. Two empirical studies have shown that countries with age-dependent minimum wages have higher levels of youth employment (Neumark and Wascher 2004; Shannon 2011), however, little is known about the ways in which the age dependency influences employment flows in the youth labor markets.

The effects of age-dependent minimum wages on employment flows have recently generated considerable policy interest and significant media attention. In the Netherlands, a nationwide campaign of youth activist groups and labor unions criticized the age dependency, arguing that it motivates employers to dismiss employees on the basis of their age (Voortman, Karabulut, and Vermeij 2015). The system has been alleged to promote churning by encouraging employers to keep replacing older, costlier workers with younger ones. In line with this reasoning, more workers are thought to experience job loss when they are close to reaching the eligibility threshold for a higher minimum wage rate. The same practices were recently discussed in the Australian media (Farrell and McDonald 2018); however, a rigorous policy debate of this phenomenon is hindered by the lack of empirical evidence supporting its existence and documenting its scale.

The aim of this article is to identify the effects of minimum wage discontinuities on labor market flows, using a population-level data set of youth workers in the Netherlands. The Dutch 
minimum wage system is particularly suited for this exercise, as it subjects youth workers to a total of nine consecutive increases of the minimum wage rate. The eligibility threshold for minimum wages is reached at the age of 15 , and the applicable rate rises in yearly increments up to the age of 23 when workers become eligible for the adult rate. The discontinuities of the minimum wage rate are sharp (the rate changes on the day of a youth worker's birthday) and economically important. They induce a substantial (15-17\%) year-on-year variation in individual labor costs, and they do so for more than $20 \%$ of the youth workforce. This rate of utilization is in a stark contrast with the US youth subminimum wage system, which is embedded in legislation but rarely used in practice because of the institutional limitations of its applicability.

My analysis rests on an administrative data set covering the entire population of the Netherlands followed over the years 2006 to 2012. The data contain detailed records of individual labor market histories, including two indicators of employment flows: the starting date (job accession) and the end date (job separation) of every employment spell observed. By linking the employment data to workers' birth records, I can assess whether the proximity to birthdays (and hence to the minimum wage discontinuities) influences the incidence of job accessions and job separations.

The empirical analysis consists of three parts. First, I conduct a descriptive analysis of job accession and job separation flows and discuss the causal mechanisms that are in line with the observed dynamics. Next, I focus on the job separation effect, quantify its size using a model of employment durations, and explore its heterogeneity with respect to workers' age, industry, and calendar time. This selective focus is motivated by the policy interest in job separations and by data limitations that complicate the analysis of job accessions. Finally, I leverage the findings of the first two parts to investigate the effect of minimum wage discontinuities on the levels of 
youth employment. Particular attention is paid to the dynamics of the employment effect.

\section{Relation to the Literature}

This article contributes to the literature on the effects of minimum wages on youth labor markets. ${ }^{1}$ It follows the example of Portugal and Cardoso (2006), Brochu and Green (2013) and Dube, Lester, and Reich (2016) by estimating the effects of minimum wage on labor market flows, and it is the first article to do so in the context of age-dependent minimum wage discontinuities. Previous studies of age-dependent minimum wages include a cross-national analysis by Neumark and Wascher (2004), who showed that the presence of a youth subminimum wage rate in national minimum wage systems reduces the disemployment effects of a minimum wage among young workers. Other studies reported similar findings using quasiexperimental designs. Pereira (2003) showed that an increase of the youth subminimum wage rate for 18- and 19-year-old workers in Portugal led to significant disemployment effects within this group of workers. Shannon (2011) studied the effects of the abolition of the youth subminimum wage rate in several Canadian provinces and found mixed evidence of disemployment effects; Hyslop and Stillman (2007) reported similarly weak evidence in the case of a reform implemented in New Zealand.

The findings presented in my study are distinct from the findings discussed above. Both the cross-country and the quasi-experimental designs investigate labor market shifts induced by changes to the age-dependent minimum wage systems. By contrast, I study a variation embedded within the age-dependent system that is triggered by individual workers crossing the age

\footnotetext{
${ }^{1}$ For a thorough overview, see Neumark and Wascher (2008) and the papers cited therein. Other studies focusing on youth employment include Yuen (2003), Brochu and Green (2013), Giuliano (2013) and Dube et al. (2016).
} 
thresholds. This approach is particularly valuable for understanding the nontrivial dynamics of labor market flows that are specific to age-dependent minimum wages, but it is less suited for evaluation of counterfactual scenarios that involve fundamental changes of the current minimum wage system.

My focus on labor market outcomes around the age discontinuities is shared with the study of Dickens, Riley, and Wilkinson (2014), who analyzed the effects of minimum wage discontinuities on youth employment levels in the United Kingdom. The authors found that the threshold-induced increase of the minimum wage rate has a positive employment effect for lowskilled individuals. The validity of their identification strategy is subject to a criticism, however, which I discuss later in this article. A recent study by Kreiner, Reck, and Skov (2019) analyzed a Danish discontinuity of the minimum wage rate that occurs on the 18th birthday and documented dynamics of employment in line with the findings of this study. Of note, the discontinuity used by Kreiner, Reck, and Skov (2017) coincides with a loosening of occupational restrictions, which may introduce bias to their findings. I demonstrate this by showing that the Dutch discontinuity, which coincides with a similar change of occupational restrictions, yields employment dynamics that differ from the discontinuities that only affect minimum wage rates.

\section{Minimum Wages in the Netherlands}

Youth minimum wages have been a central part of the Dutch labor legislation for more than 40 years. Since 1974, youth minimum wages have been defined as a stepwise increasing function of a worker's calendar age with each wage rate expressed as a fixed percentage of the adult minimum wage. The applicable percentages were subject to several changes, but have remained constant since 1983. The system distinguishes nine age brackets, starting at age 15 and reaching 
the adult rate at age 23. The minimum wage applies to almost all types of labor, except for internships ( $7 \%$ of youth employment spells) and self-employment $(0.5 \%$ of youth employment spells). The real value of minimum wage is stable — unlike the US system, the Dutch system is indexed to inflation and the rates are updated twice a year.

\section{[Figure 1 about here]}

Figure 1 illustrates the age dependence of Dutch minimum wages. The nominal increments of the minimum wage rate become more pronounced with each calendar age, but the relative increments are fairly consistent: At every step, the minimum wage rate rises by 15 to $17 \%$ compared to the previous rate. The difference between the initial youth rate and the adult rate is pronounced: In 2010 , the hourly minimum wage rate for 15 -year-olds was $€ 2.57$, whereas the adult rate was $€ 8.55$.

Along with the minimum wage, other age-dependent policies can influence labor market decisions of young workers. Most important, heavy restrictions are placed on the types of jobs that can be performed by workers aged 15 or less. Most of the occupational restrictions are lifted on the 15th and 16th birthday, but a subset is retained up to the age of 18 . The gradual alleviation of labor restrictions should be borne in mind when interpreting the employment flows around these focal ages. A detailed description of all age-dependent labor restrictions and other relevant labor market institutions is presented in Online Appendix A.1

\section{Data}

\section{Overview of the Data Set}


The data set is constructed from several administrative sources collected by Statistics Netherlands (CBS). It covers the entire population of the Netherlands (17 million inhabitants), who were followed from January 2006 to December 2012. The employment data are collected by the Tax and Customs Administration and contain exhaustive information about workers' labor market histories. This information includes gross monthly earnings, sector of employment, number of days spent at work, regular work intensity (specified as a fraction of full-time equivalent hours), and most important, the dates of job accession and (if observed) job separation for each employment spell observed. The limitation of the data is that the job separation records do not distinguish whether a separation was voluntary or involuntary.

The employment data are linked to municipal registers, which record the date of birth and a basic set of demographic characteristics for every Dutch resident. The exact day of birth is not observable - to ensure personal privacy, the individual information is restricted to the year and month of birth. Nevertheless, this information is enough to approximate how many months were remaining to workers' birthdays at the points of their job accessions and job separations.

\section{Descriptive Statistics}

In this section I describe the characteristics of Dutch workers who are directly affected by the minimum wage discontinuities (that is, workers aged 15 to 23). Labor participation among 15 - to 23-year-olds is high: $70.7 \%$ engage in some form of paid work within the span of a calendar year. Table 1 reports summary statistics corresponding to this group of workers.

\section{[Table 1 about here]}


The average age of workers in the sample is 19.2 years, and young women are shown to be just as likely to work as young men. Many workers have immigrant backgrounds, with firstand second-generation immigrants representing approximately $21 \%$ of the youth workforce. The average duration of a youth employment spell is 13.9 months and the average work intensity is $47 \%$ of the full-time equivalent. This work intensity corresponds to approximately 4 hours of work per workday. Both the spell durations and the work intensities are strongly dependent on the age of workers, and this dependency is reflected in the size of corresponding standard deviations. The duration of the employment spells increases with age, which is partly a mechanical effect stemming from the increasing tenure of individual workers, but it also reflects the gradual shift from seasonal and casual work to more permanent forms of employment. The same effect applies to the intensity of work, which rises from minimal part-time work allocations of the 15-year-olds to full-time allocations of adult workers.

The first panel of Figure 2 plots the share of people who are recorded as employed between the ages 13 and 25 . Note that this employment rate is lower than the annual participation rate, since a considerable share of youth workers engages in seasonal jobs and other short-term work arrangements.

\section{[Figure 2 about here]}

The employment rate starts rising sharply once teenagers reach the age of 15, which coincides with the loosening of the most stringent occupation restrictions. The growth decelerates throughout the teenage years, although the positive trend is sustained even among workers in their early twenties. The mean annual earnings for workers aged 15 to 23 is $€ 6674$, which is approximately $40 \%$ of the full-time adult minimum wage per annum. The gross hourly 
wages average $€ 7.9$ per hour and they exhibit substantial variance driven by the long upper tail of the wage distribution. A transformation of this distribution is presented in the first panel of Figure 3 Here, the gross hourly wages are expressed relative to the minimum wage rate applicable for each worker's age group.

\section{[Figure 3 about here]}

The density starts rising sharply above 1 , which is the point of identity between the observed wages and the minimum wage rate. Although most of the workforce earns wages well above the minimum levels, a small fraction is recorded to earn wages below the legal minimum. ${ }^{2}$ The overall shape of the wage distribution is, however, consistent with the assumption that the minimum wage constitutes a binding minimal amount of earnings that can be generated from formal employment.

This statement is also supported by the second panel of Figure 3, which tracks the evolution of the average gross hourly wage over the lives of young workers. The average wage for the non-exempt workers is shown to increase in a series of discrete steps coinciding with the birthday discontinuities of the Dutch minimum wage system. The birthdays following the last minimum wage discontinuity show no discrete change of the workers' wage level, and the same is also true for the wages of workers who are not subject to the minimum wage legislation.

The stepwise trajectory of average wages reveals that a sizable share of the workforce is directly affected by the minimum wage discontinuities. The size of this group can be

\footnotetext{
${ }^{2}$ In the observed period, $2 \%$ of the workers eligible for minimum wages were recorded to earn wages below the applicable minimum rate. This discrepancy is well-documented in the literature (see Flinn 2011) and its occurrence can be attributed to many causes, including firms' failure to comply with the legislation, reporting errors, or issues with treatment of employment spells with irregular working hours.
} 
approximated by monthly earnings data, which indicate that $21 \%$ of workers aged 15 to 22 earn wages below the minimum wage rate applicable after their next birthday. The share of workers in this category is relatively stable throughout the teenage years, but it starts falling when workers reach their 20th birthday (see the gradual attenuation of steps in the average wage profile).

\section{Employment Dynamics}

Figure 2 shows that the employment levels increase with age, although minor disturbances of the general trend seem to occur around workers' birthdays. The disturbances become more apparent in the second panel of Figure 2, in which I restrict the exposition to adult workers. To see whether these are caused by flows in or out of employment, I quantify the number of job accessions and job separations recorded within the same monthly age brackets (the exact definitions of the job accessions and job separations are given in Online Appendix A.2). The resulting age profiles of job accessions and job separations are shown in Figure 4.

\section{[Figure 4 about here]}

The age profile of the job accession incidence is dominated by two spikes that follow workers' 15 th and 16th birthdays. These birthdays mark the alleviations of stringent occupational restrictions imposed on the types of jobs that can be performed by teenagers. ${ }^{3}$ In the following years, the job accession incidence is mostly falling. The job separation incidence rises in the first four years, driven by the fast expansion of the youth workforce evidenced in Figure 2. The

\footnotetext{
${ }^{3}$ A smaller spike following the 18th birthday is also likely to be influenced by the loosening of job restrictions.
} 
incidence peaks between the ages 18 and 19 and starts falling thereafter, thus suggesting better job retention among older workers (who are more experienced and better educated).

Apart from the general trend, Figure 4 also reveals the dependence of job accessions and job separations on the proximity to workers' birthdays. The job accessions are shown to increase shortly after the birthdays, and the upward shift of the job accession incidence is sustained throughout the following months. The job separations exhibit short spikes prior to workers' birthdays, but unlike the job accessions, the incidence of job separations does not seem to be elevated past the birthday discontinuities. To illustrate these two dynamics clearly, I pool the data underlying Figure 4 and calculate the average incidence of job accessions and job separations at different monthly proximities to the next birthday. Figure 5 plots the averages corresponding to the birthdays that are not associated with the confounding changes of occupational restrictions (this excludes 15 th, $16^{\text {th }}$, and 18 th birthdays). ${ }^{4}$

\section{[Figure 5 about here]}

To highlight the level shifts (or the lack thereof) of the two plotted outcomes, the averages in Figure 5 are accompanied by trailing lines that approximate the initial trends of job accessions and job separations and extrapolate them past the birthday discontinuities. Also observable here, the job accession incidence is higher after workers' birthdays, with the break occurring in the first month following the discontinuity. The shift of average job accession incidence corresponds to approximately 100 to 200 cases per month per year. The job separations are shown to spike in an isolated window of three months prior to workers'

\footnotetext{
${ }^{4}$ In addition, Online Appendix Figure B.1 presents raw job separation and job accession incidence in the 12 months surrounding each of the birthdays affected by the discontinuities.
} 
birthdays, raising the average job separation incidence by approximately 250 cases per year in total.

The pre-birthday spike of job separations shows that more jobs are terminated just before workers become eligible for higher minimum wage rates. Such dependence is in line with the argument used by the Dutch labor unions, and it is indeed suggestive of employers acting on the minimum wage discontinuities. An alternative explanation of the job separation spike involves workers targeting a specific level of income. The argument is that some workers may decide to end their employment prior to their next birthday because with the higher minimum wage rate they do not need to work as much to earn their target income. Accordingly, they will switch to a less-intensive job that is sufficient to reach their desired income level. I have looked for empirical evidence in support of this explanation but find no indication of the income-targeting behavior.

The post-birthday shift of job accessions shows that more workers enter the labor market after they become eligible for higher minimum wage rates. This dependence could be attributed to several mechanisms. First, it may be a mechanical consequence of the preceding spike of job separations: since a disproportionate number of workers have their employment spells terminated prior to their birthday, the subsequent increase of job accessions could be evidence of them finding new jobs. This mechanism is certainly at play, since more than $80 \%$ of workers whose jobs were terminated within the spike are observed to find a job in the next six months. The cumulative increase of job accessions appears to be larger than the initial job separation spike, however, which necessitates the presence of other mechanisms. These may include the labor 
market entry of workers with higher reservation wages ${ }^{5}$, or selective hiring behavior of firms who are looking for job applicants of a particular calendar age.

The exact nature of the mechanisms underlying the job accession effect is difficult to ascertain because of the limitations of administrative data. The data fall short of tracking jobsearch behavior of youth workers, which means that the post-birthday changes of job accessions cannot be compared to the changes of the underlying pool of youth job-seekers. This is a problem for teasing apart the mechanisms involving reservation wages and job postings, because the primary difference between the two mechanisms is that the former expands the post-birthday pool of job-seekers whereas the latter does not. Without the job-search information, it cannot be determined whether the job accession effect is driven by workers or firms. The lack of job-search information also hinders efforts to analyze the effect of the discontinuities on the job-finding rate. Indeed, with a sufficiently tight job market, the post-birthday increase of the job accessions could be smaller than the increase of the pool of job-seekers, resulting in a lower job-finding rate and a higher rate of youth unemployment.

In the next section, I investigate the effects of minimum wage discontinuities on job separation incidence in a multivariate econometric analysis of employment durations. The onesided focus is motivated by the explicit policy interest in identifying and quantifying the effects of age-dependent minimum wages on job separations. It is also motivated by the lack of data on

\footnotetext{
${ }^{5}$ This argument draws on monopsony models pioneered by Robinson (1933) and extended by Burdett and Mortensen (1998) and Manning (2003). In an economy where firms extract rents from workers by holding wages below the equilibrium level, an increase of the minimum wage rate can raise the labor market entry of minimum wage workers. Positive employment effects (or absence of disemployment effects) of an increase of the minimum wage have been found by several empirical studies (Katz and Krueger 1992; Card and Krueger 1994; Giuliano 2013). Other studies challenge this view, finding evidence of negative employment effects (see Neumark and Wascher 2007; Thompson 2009; Sabia, Burkhauser, and Hansen 2016).
} 
job search, which precludes a parallel analysis of job accessions. Nevertheless, I return to the dual-sided focus in the final section, in which I quantify the effects of the discontinuities on overall levels of employment.

\section{Econometric Analysis: Job Separation Effects}

\section{Models of Employment Duration}

I use the monthly employment data underlying the preceding analysis to estimate a complementary log-log model of employment duration with time-varying covariates. The dependent variable is the probability of job separation $s$, which is expressed as

$$
\begin{aligned}
\operatorname{Pr}\left[s_{i t}=\right. & \left.1 \mid \mathbf{x}_{i t}\right]=1-\exp \left(-\exp \left(\mathbf{x}_{i t}^{\prime} \boldsymbol{\beta}\right)\right), \\
\mathbf{x}_{i t}^{\prime} \boldsymbol{\beta}= & \alpha+\beta \log \left(\text { dur }_{i t}\right)+\sum_{j=1}^{3} a g e_{i t}^{j}\left(\gamma_{j} \cdot \mathbf{1}\left(\text { age }_{i t} \leq 17.5\right)+\delta_{j} \cdot \mathbf{1}\left(\text { age }_{i t}>17.5\right)\right) \\
& +\sum_{m=1}^{11} \zeta_{m} \cdot \mathbf{1}\left(\text { mtbd }_{i t}=m\right)+\sum_{m=1}^{11} \eta_{m} \cdot \mathbf{1}\left(\text { calend }_{t}=m\right) \\
& +\sum_{m=1}^{11} \theta_{m} \cdot \mathbf{1}\left(\text { birth }_{i}=m\right)+\sum_{j=2006}^{2010} \boldsymbol{l}_{j} \cdot \mathbf{1}\left(\text { year }_{t}=y\right) .
\end{aligned}
$$

Subscript $i$ denotes workers and $t$ denotes calendar time. The set of covariates (x) includes a constant, the logarithm of employment duration (dur), a cubic spline function of a worker's age, and four sets of dummies. The flexible spline function of age is chosen to capture the nonlinearities of the age-specific job separation rate, as evidenced in Figure 4. The knot of the spline is set at 17 years and 6 months of age, which ensures a good fit of the model, and loosely differentiates between the workers who attend high school, and older workers. The main variables of interest are contained in the first set of dummies ( $m t b d)$. The $m t b d$ dummies indicate 
how many months are remaining to a worker's birthday at the point of observation. The corresponding coefficients $\zeta$ capture whether the workers are, ceteris paribus, more likely or less likely to have their employment spell terminated at specific monthly proximities to their birthday. The other three sets of dummies indicate the birth month of the worker (birth), the current calendar month (calend), and the current year (year). The birth month and calendar month dummies are added to control for potential age-specific confounders. The mtbd dummies are identified through the interaction of calendar months and birth months.

The data set consists of employment spells of non-exempt workers who are in the age range that is affected by the minimum wage discontinuities. For the baseline specification, I discard the employment spells that end prior to the age of 15 years and 6 months or that start past the age of 23 years and 5 months. The spells spanning either of the two cutoff ages are kept in the data set, but the parts of spells preceding the lower cutoff age (or following the upper cutoff age) are truncated. The spells of workers who are either exempt or older than the upper cutoff age are later used for falsification tests. In addition to the truncation, I restrict the period of observation to years 2006 to 2011. The last available year (2012) is not analyzed as I cannot rule out that the jobs recorded to end this year were not resumed in the year 2013. The model is estimated by maximum likelihood and the results are presented in Table 2 .

\section{[Table 2 about here]}

The parameter estimates are reported in exponentiated form and can be interpreted as an approximation of the odds ratio. Coefficients higher (lower) than 1 imply a higher (lower) relative risk of job separation compared to the baseline case. The $m t b d$ coefficients reveal the pattern presented graphically in Figure 6. 


\section{[Figure 6 about here]}

Here, the coefficients are expressed as percentage changes in the baseline job separation rate, which corresponds to the workers who are seven months short of their next birthdays. The job separation probabilities are indistinguishable from the baseline in all months except for the three that are closest to workers' next birthdays. Within this quarter, the aggregate job separation probability increases by 0.6 to $1.5 \%$ and remains significantly higher than the baseline.

The stable profile of the job separation probabilities with a single peak preceding workers' birthdays is consistent with the behavior of employers dismissing their employees based on their age. The cost-minimizing employers have little incentive to act upon the agedependency when workers are far from their birthday, but they will take it into account when the changes of individual labor costs become imminent. The increase of the job separation probability within these three months is therefore interpreted as the effect of minimum wage discontinuities. ${ }^{6}$

With respect to the other covariates, several patterns emerge. The duration of employment is found to reduce the risk of job separation, reflecting the higher job-specific experience and better screening of tenured workers. Job separations are subject to a strong seasonality that peaks in August, indicating the end of summer holiday jobs, and in December, the end of the year. The birth month dummies show that the workers born in December and

\footnotetext{
${ }^{6}$ The spread of the effect over the period of three months is likely attributable, in part, to measurement error in the variable indicating proximity to birthdays. Since the exact dates of birth remain unobserved, the variable is subject to measurement error, and some workers are assigned birthday proximities that are one month shorter (or longer) than their actual proximities. This measurement error can cause the estimated effect to "spill over" to the two months adjacent to the month in which the effect actually manifests.
} 
January are at a relatively high risk of job separation, which may be related to the fact that their birthdays take place around the time firms tend to make hiring and firing decisions. Higher job separation for workers born in January and December is also in line with the findings of Buckles and Hungerman (2013), who used US census data to show that babies born in these two months are more likely to come from disadvantaged backgrounds. The economic and social disadvantage may influence the odds of keeping a job, rendering the workers born in winter months more vulnerable to minimum wage discontinuities.

Note that the estimated effect of minimum wage discontinuities is expressed in terms of changes of the aggregate job separation probability, although it is borne only by a subset of the youth workforce. The workers who can retain their former wages are unlikely to face higher odds of job separation close to their birthdays. Only those workers who are earning wages below the next increment of the minimum wage rate are directly at risk, as their labor costs are bound to change when they reach the discontinuity. This group represents approximately $21 \%$ of the youth workforce, suggesting that the effect of the minimum wage discontinuities for workers who are directly at risk is considerably larger than the aggregate effect.

One way to demonstrate the effect size in relation to the size of the affected group is to compare the effect size to the magnitude of wage changes induced by the discontinuities. This can be done by dividing the aggregate job separation effect ( $1.0 \%$ in the affected quarter) by the change of the average wage rate at the discontinuity ( $6.3 \%$, accounting for the underlying trend). This calculation yields a wage elasticity of the job separation effect, which equals 0.21 (additional details on its calculation can be found in the notes of Online Appendix Table B.1).

\section{Heterogeneity of Job Separation Effects}


In this section, I evaluate heterogeneity of the job separation effect, focusing on several dimensions: calendar age, calendar time, and workers' characteristics. The analyses are done using adjusted specifications of the principal model, with the common change being that the set of $m t b d$ dummies has been replaced by a single dummy representing the three months closest to workers' next birthdays. This approach facilitates the exposition and comparison of groupspecific results.

Age-Specific Effects

To derive the age-specific effects, I employ a duration model that restricts the data to a 12-month window around the respective discontinuities and uses a quadratic age polynomial instead of the cubic spline. The model is estimated for each age group affected by the discontinuities and also for workers aged 24 to 26. The first panel of Figure 7 shows the corresponding effect estimates.

\section{[Figure 7 about here]}

The age profile of the birthday effects resembles a sawtooth pattern. The effect is high for 16-year-olds, which is to be expected as this is the youngest (and the least-skilled) group of workers in the analyzed population. The size of the effect falls in the two following years and rebounds when workers reach the age of 19 . This outcome is likely attributable to an inflow of inexperienced workers who have joined the labor force only after finishing high school. The effect then starts to decline again and becomes insignificant at the age of 22. This is in line with the falling share of workers in minimum wage jobs, and with better screening for older workers' abilities. The effects attributed to 23rd and 24th birthdays seem to increase again (the 23rd birthday follows college graduation) but neither proves significant. I find no dependence in the following years, which should also be the case since the workers are no longer subject to the 
minimum wage discontinuities. Online Appendix Table B.1 lists wage elasticities corresponding to each of the birthday discontinuities.

\section{Time-Specific Effects}

Another informative dimension of heterogeneity is the calendar time-especially since the period of observation includes the global financial crisis, and it is reasonable to expect that the magnitude of the minimum wage effect depends on the phase of the business cycle. Indeed, Clemens and Wither (2019) have documented that the US minimum wage changes that occurred just prior to and during the global financial crisis had an unusually large impact on low-skill employment. To see if similar patterns emerge in the Dutch context, I estimate the job separation model separately in three time periods: the peak of the business cycle (2006Q1-2008Q2), the crisis (2008Q3-2009Q4), and the recovery (2010Q1-2011Q4).

The estimates corresponding to this analysis are presented in the second panel of Figure 7 and show a dependence in line with the economic rationale: prior to the crisis, the birthday discontinuities were associated with a $1 \%$ increase of the job separation rate; during the recession, this effect became 0.4 percentage points stronger; after the recession, it fell to $0.8 \%$. The higher effect during the recession suggests that employers facing worse economic conditions become more cost-sensitive and engage in more employee screening than they would otherwise. The decrease of the effect size in the following period is likely attributable to the gradual improvement of economic conditions and a higher level of abilities among workers who managed to retain their jobs throughout the recession. The finding of a higher job separation effect during the crisis echoes the findings of Clemens (2019), who shows that, during the crisis, countries with statutory minimum wage regimes experienced larger declines in their young adult 
employment rates than did countries with national collective bargaining regimes.

\section{Worker-Specific Effects}

Last, I focus on worker's characteristics. To explore who is more likely to lose their job due to the discontinuities, I estimate a variant of the principal model that distinguishes among the birthday effects by workers' gender, immigration status, and the sector of employment. In terms of sector, I distinguish retail establishments, supermarkets, and bars and restaurants. Together, they account for $46 \%$ of the observed employment spells, and they represent industries that are often analyzed in the minimum wage literature (see Giuliano 2013; Dube et al. 2016). The regression results show no significant difference by workers' gender and immigration background (see Online Appendix Table B.2).

The sectoral estimates, presented graphically in the third panel of Figure 7, reveal a sizable heterogeneity of the minimum wage effects. The effect is found to be significantly larger in the supermarket sector, a sector that accommodates approximately $15 \%$ of the youth workers. The effects are smaller for other retail businesses, and for restaurants and bars. The latter two sectors are shown to have effects higher than the effects for all the remaining sectors combined, but the difference is not statistically significant.

The last column in Figure 7 comes from a separate model that evaluates the birthday effects for interns and apprentices. As discussed above, these workers are not legally subject to the minimum wage regulation, and so they can be considered a placebo group. ${ }^{7}$ Employers

\footnotetext{
${ }^{7}$ Internships constitute an integral part of the Dutch youth labor market. For many students, internships serve as the point of entry into professional labor markets. Workers may engage in internships as part of their secondary vocational education (ages 16-17); however, a vast majority of internships is observed among older workers (the average age of an intern is 20 years of age). The data show that the internship spells last on average six months, and they generally yield wages below the minimum wage rate.
} 
should have no particular reason to dismiss these workers close to their birthdays, and this is precisely what is evident in the figure. For interns and apprentices, the probability of job separation close to their next birthday is the same as the probability of job separation in other times of the year. Identical results are found for another placebo group — public sector workers. Jobs in the public sector start at salaries that are strictly above the wage level subject to minimum wage discontinuities, and therefore no birthday effect is to be expected. Such jobs account for $4 \%$ of youth employment spells, and the youngest workers are 17 years old. These jobs cover entry-level clerical appointments, administrative support in various public institutions, and new recruits in the Dutch military. The full set of results for both placebo groups is included in Online Appendix Table B.2.

\section{Effect Size and the Bite of the Discontinuities}

Next, I leverage the heterogeneity analyses to investigate the relationship between the magnitude of the job separation effects and the "bite" of the minimum wage discontinuities. Here, the bite denotes the expected share of workers for whom the discontinuities are strictly binding. The hypothesis is that the effect heterogeneity uncovered in the previous sections should be at least partially attributable to the differences in the bite of the policy. In other words, I expect to see larger job separation effects among groups of workers whose wages do not grow fast enough to surpass the higher minimum wage rate by the time they reach their next birthday.

To test this hypothesis, I split the youth workers into a grid of mutually exclusive timesector-age cells and calculate both the job separation effect and the expected bite of the discontinuities separately for each of the worker cells. The cells are defined as follows. In terms of calendar time, I distinguish among the peak, the recession, and the recovery period. In terms 
of sector, I distinguish among retail, supermarkets, bars and restaurants, public sector, and the remaining sectors. In terms of age, I distinguish between workers in the secondary school age group (age 18 and less) and older workers (ages 19-23). ${ }^{8}$ This $3 \times 5 \times 2$ grid structure yields 27 distinct cells ( 3 cells for teenage workers in the public sector are not used due to the lack of data).

The expected bite of the policy is calculated as follows. First, I take all workers who were employed when they were 11 months from their next birthday. I predict their wage rate in 11 months from this point using their current wage rate and a measure of counterfactual wage growth (in this case, I use the predicted wage growth among workers in the same sector who are aged 23.5 to 25.5 and who are observed in the same time period). With this information, I quantify the expected bite of the policy as the share of workers whose predicted counterfactual wage is lower than the minimum wage rate applicable on their next birthday. ${ }^{9}$ I estimate the job separation effects with a variant of the principal model, which uses a cubic age polynomial.

\section{[Figure 8 about here]}

Figure 8 plots the cell-specific job separation effects against the cell-specific expected bite of the discontinuities. The expected bite ranges from $8 \%$ to $37 \%$, and the effect sizes range from $0 \%$ to $6 \%$ (with one outlier at $-4 \%$ ). As predicted in the initial hypothesis, the effect sizes

\footnotetext{
${ }^{8}$ A trade-off between the precision of coefficient estimates and the granularity of age-by-industry-by-year cells exists, which led me to restrict the age dimension to two groups. The selected groups distinguish two prominent age categories in my data while keeping the number of observations in each cell reasonably high. A replication of this exercise with eight calendar-age cells yields qualitatively similar results, but its graphical exposition is distorted by the lower precision of coefficient estimates.

${ }_{9}^{9}$ Accounting for the counterfactual wage growth is a critical step of the prediction procedure. This is illustrated by the case of the supermarket sector, which employs fewer minimum wage workers than the retail and hospitality sector, but at the same time it is subject to a larger bite of the policy because of a very low sector-specific wage growth.
} 
appear to be increasing in line with the expected bite of the policy. A line drawn through the presented data is upward sloping with a significantly positive slope coefficient, indicating that a $10 \%$ increase in the expected bite translates into a 1.14 percentage point increase of the job separation effect. It can be confirmed, therefore, that the effect heterogeneity reflects the differences in the share of workers affected by the minimum wage discontinuities.

\section{Robustness Checks and Discussion}

The results of the employment duration analysis have been subjected to several robustness checks. The effects are not sensitive to: 1) the inclusion of dummies for standard durations of employment contracts (6 months and 12 months), 2) inclusion of dummies for monthly employment durations, or 3) probit and logit specifications of the error terms.

Focusing on workers' subsequent labor market outcomes, I conduct a supplementary analysis in which I calculate workers' hourly wage growth over the next three years. The analysis shows that the workers who experienced a job termination within the pre-birthday spike are subject to a $1 \%$ lower wage growth compared to their colleagues who managed to keep their jobs. This finding suggests that employers are screening effectively, dismissing employees with worse labor market prospects than their firm-level peers. The job termination itself, however, does not lead to a protracted unemployment spell and a loss of human capital, which is in stark contrast to the negative impacts of job loss for older workers (see, e.g., Jacobson, LaLonde, and Sullivan 1993; Currie and Fallick 1996; Couch and Placzek 2010). As indicated earlier, youth workers generally manage to gain re-employment shortly after the job termination, an outcome likely related to poor vetting procedures and minimal skill requirements for minimum wage jobs. 


\section{Econometric Analysis: Employment Levels}

In this section I explore whether the identified spike of job separations translates to a change of employment levels, and to what extent this effect might be compensated for by the post-birthday increase of job accessions.

The analysis of employment levels is central to the article of Dickens et al. (2014), who evaluated the effects of a minimum wage discontinuity that occurs when British workers turn 22. Using a regression discontinuity design (RDD), the authors found that the minimum wage increase has a positive effect on aggregate employment of low-skilled individuals. A similar exercise could be performed in the Dutch context as well, but the identified dynamics of labor market flows point to several problems with this approach.

First, the RDD uses the no-anticipation assumption to justify that the comparison of employment trends before and after the discontinuity captures the true effect of the minimum wage rate change. The observed spikes of job separations show that this assumption is violated, however, since employers anticipate the increase of workers' labor costs and terminate their contracts ahead of their birthdays. This violation leads to an upward bias of the RDD estimate of the employment effect. Second, Figure 5 shows that the job accession effect is sustained throughout the post-birthday period. This means that rather than causing a discontinuous jump of the employment rate, the higher rate of labor market entry speeds up the growth of the employment rate in the post-birthday period. Such dependence leads to a downward bias of the RDD estimate of the employment effect.

Borrowing from the research design of Dickens et al. (2014), I evaluate the employment outcomes within isolated time intervals around the birthday discontinuities. Dickens et al. used an interval of 24 months, whereas I use shorter intervals of 18 months. This restriction is 
necessitated by narrower spacing of age-dependent discontinuities in the Dutch system. To address the biases discussed above, I implement two adjustments to the RDD model. First, to account for the violation of the no-anticipation assumption, I use a donut-hole design that excludes the employment outcomes observed in the three months closest to workers' birthdays. This exclusion ensures that the pre-trend estimated by the RDD model is not influenced by the anticipatory behavior observed in the months immediately preceding the discontinuities. Second, to account for the post-birthday changes of the employment growth, I add a "kink" to the model specification, turning the model into an RDD with a regression kink design (RDD-RKD) as in Nielsen, Sørensen, and Taber (2010). The functional form of the estimated model is as follows,

(2) $E M P_{i t}=\alpha+\sum_{j=1}^{2} \beta_{j} \cdot\left(\text { age }_{i t}-B D\right)^{j}+\mathbf{1}\left(\right.$ age $\left._{i t}>B D\right) \cdot\left(\gamma+\delta \cdot\left(\operatorname{age}_{i t}-B D\right)\right)+\varepsilon_{i t}$,

where $E M P$ denotes individual labor market participation, $B D$ is equal to the age attained at the analyzed birthday discontinuity, and $\varepsilon$ is the residual. The model uses a quadratic age polynomial centered at the discontinuity and augmented by a linear kink term. The quadratic polynomial accounts for the concavity of the employment rate with respect to age (as illustrated in Figure 2). The key coefficients of interest are $\gamma$ (which represents the RDD change of the employment level at the point of discontinuity) and $\delta$ (which represents the RKD slope change following the discontinuity). The model is estimated by OLS, and uses pooled data corresponding to the same set of birthday discontinuities as plotted in Figure 5 (excluding $15^{\text {th }}, 16^{\text {th }}$ and $18^{\text {th }}$ birthdays). The results are reported in Table 3 .

\section{[Table 3 about here]}

The RDD effect $\gamma$ is negative and statistically significant, indicating that the employment 
rate drops by approximately 0.3 percentage points at the birthday discontinuity. The RKD effect $\delta$ is positive and statistically significant, indicating that in each month past the discontinuity, the growth of the employment rate is 0.05 percentage points higher than it is prior to the discontinuity. This outcome means that the immediate negative effect of the job separation spike (measured by the RDD effect) is gradually neutralized by the higher rate of labor market entry (measured by the RKD effect), becoming positive in 5 to 6 months past the discontinuity. A graphic illustration of this dependence is presented in Figure 9, which plots the observed and the

fitted values of the employment rate. The initial drop is neutralized at the point where the solid line of fitted values crosses the dashed line, which represents the age profile without the RDD and RKD effects.

\section{[Figure 9 about here]}

This analysis reinforces the discussion of mechanisms behind the job accession changes, showing that the post-birthday increase of job accessions cannot be explained solely by the mechanical effect stemming from re-employment of workers who were dismissed as a result of the minimum wage discontinuities.

\section{Robustness Checks and Discussion}

The results of the RDD-RKD model have been subjected to a variety of robustness checks, including estimating a model with: 1) a quadratic kink term, 2) a cubic age polynomial and a cubic kink term, 3) a range of shorter time intervals around the birthday discontinuities, 4) a control set of covariates corresponding to workers' observable characteristics, and 5) probit and logit specifications of the error term. The results of these robustness checks are not significantly 
different from the results presented in Table 3 (Online Appendix Table B.3 lists select coefficient estimates).

I have also estimated age-specific variants of the RDD-RKD model for workers aged 17 to 23. The RDD and RKD coefficients corresponding to these models are listed in Online Appendix Table B.4. The models for ages 17 and 19 to 23 are in line with the principal specification, yielding negative RDD estimates and positive RKD estimates. The model for age 18 yields a negative RKD estimate, which is likely attributable to the spike of job accessions that follow the 18th birthdays. This finding illustrates the identification problems associated with discontinuities that coincide with changes of occupational restrictions.

Note that the violations of RDD assumptions discussed in the beginning of this section should be taken seriously. My job separation analysis reveals clear signs of anticipatory behavior from forward-looking firms, and the failure to account for these employment dynamics can have profound consequences for empirical analyses of age-dependent minimum wage systems. To illustrate this, I have conducted a series of analyses using the original specifications of Dickens et al. (2014), which do not employ the donut-hole design. The results reveal that the failure to account for the anticipatory behavior leads to a considerable bias of the RDD coefficient, effectively halving the size of the estimated short-run effect. ${ }^{10}$ Similarly, the absence of an interpretable kink term conceals the positive effect of higher minimum wage rates in the months following the birthday discontinuities and leads to a downward-biased estimate of the long-run employment effect.

\footnotetext{
${ }^{10}$ This issue is further worsened if I use flexible spline specification of age controls, since it allows the model to approximate the pre-birthday drop of employment with a high degree of precision, thus eliminating most of the RDD effect.
} 


\section{Conclusions}

This article provides evidence of the effects of age-dependent minimum wages on labor market flows and employment levels among Dutch youth workers aged 15 to 23 . The age dependency is an important feature of the Dutch minimum wage system - it increases the youth minimum wage rate by more than $300 \%$ in the span of 8 years. The empirical analysis exploits the fact that workers face a sharp discontinuity in minimum wage rates when they turn one year older. Because of this discontinuity, firms have incentive to dismiss workers who are approaching their birthday and replace them with younger job applicants. Conversely, workers may respond to the discontinuities as well, and base their decision to enter the labor market on the applicable minimum wage rate.

Using administrative records for the entire population of the Netherlands, I analyze monthly flows in and out of the youth employment pool while accounting for the time remaining until workers' next birthdays. The results show a statistically significant increase in the incidence of job separations prior to the discontinuity: The aggregate job separation probability increases by 0.6 to $1.5 \%$ in the three months closest to workers' birthdays, compared to the rest of the year. The effect exhibits substantial heterogeneity, with its size being dependent on a worker's age, phase of the business cycle, and sector of employment. The supermarket sector in particular is shown to be responsive to the discontinuities, with the aggregate job separation probability increasing by $2 \%$, compared to the $0.9 \%$ increase applicable for the other sectors. The effect of the discontinuities is larger at ages that mark the influx of inexperienced workers into the labor force. Otherwise, the effect decreases with age, a finding in line with a falling share of minimum wage jobs, a higher prevalence of permanent contracts, and better screening for abilities of 
tenured workers. The effect also varies with the business cycle, being larger during the recession. The caveat of the job separation analysis is that I cannot distinguish between employer-initiated layoffs and employee-initiated quits. The presented empirical evidence is, however, strongly suggestive that the effects do represent layoffs made by cost-optimizing employers.

The incidence of job accessions is shown to increase after workers reach the birthday discontinuities. Compared to the preceding spike of job separations, the higher rate of job accessions is sustained throughout the months that follow workers' birthdays. This dependence results in a dynamic effect on the overall level of employment: The employment rate is initially subject to a level drop of 0.3 percentage points caused by the spike of job separations. This drop is compensated for by a higher growth rate of employment in the following months and the cumulative effect becomes positive six months past the birthday discontinuities. Importantly, the positive cumulative effect means that the increase of job accessions cannot be fully attributed to the re-employment of workers who were initially dismissed due to the minimum wage discontinuities. The sustained profile of the job accession effect is suggestive of post-birthday entry of workers with higher reservation wages, or selective hiring behavior of firms who are looking for job applicants of a particular calendar age.

The results of my analysis show that employers and employees both are likely to respond to the minimum wage discontinuities, resulting in a complex pattern of labor market flows. I should add, however, that although the presented results help us understand the labor market dynamics within the age-dependent minimum wage systems, they are not particularly suited for evaluation of counterfactual scenarios that would fundamentally change the design of the agedependent systems - an example being a reform replacing the youth subminimum wage rates by 
the adult rate. In such a case, the job separation effects would be moderated by the fact that employers could no longer replace their current employees with a cheaper substitute workforce (although a large enough change might motivate firms to switch to less labor-intensive modes of operation, thereby eliminating the need for minimum wage labor altogether). The job accession effects would be also moderated, since the mechanical re-employment effect following the initial increase of job separations would be eliminated in the first few months following the implementation of the reform. An evaluation of such counterfactual simulations needs an alternative research design, preferably one that exploits a reform of an age-dependent minimum wage system, such as the recent introduction of a national living wage for workers aged 25 and above in the United Kingdom.

\section{[[H1]] References}

Brochu, Pierre, and David A. Green. 2013. The impact of minimum wages on labour market transitions. Economic Journal 123(573): 1203-35.

Buckles, Kasey S., and Daniel M. Hungerman. 2013. Season of birth and later outcomes: Old questions, new answers. Review of Economics and Statistics 95(3): 711-24.

Burdett, Kenneth, and Dale T. Mortensen. 1998. Wage differentials, employer size, and unemployment. International Economic Review 39(2): 257-73.

Card, David, and Alan B. Krueger. 1994. Minimum wages and employment: A case study of the fast-food industry in New Jersey and Pennsylvania. American Economic Review 84(4): $772-93$.

Clemens, Jeffrey. 2019. Cross-country evidence on labor market institutions and young adult employment through the financial crisis. Southern Economic Journal 86(2): 573-612.

Clemens, Jeffrey, and Michael Wither. 2019. The minimum wage and the Great Recession: Evidence of effects on the employment and income trajectories of low-skilled workers. 


\section{Journal of Public Economics 170: 53-67.}

Couch, Kenneth A., and Dana W. Placzek. 2010. Earnings losses of displaced workers revisited. American Economic Review 100(1): 572-89.

Currie, Janet, and Bruce C. Fallick. 1996. The minimum wage and the employment of youth: Evidence from the NLSY. Journal of Human Resources 31(2): 404-28.

Dickens, Richard, Rebecca Riley, and David Wilkinson. 2014. The UK minimum wage at 22 years of age: A regression discontinuity approach. Journal of the Royal Statistical Society: Series A (Statistics in Society) 177(1): 95-114.

Dube, Arindrajit, T. William Lester, and Michael Reich. 2016. Minimum wage shocks, employment flows, and labor market frictions. Journal of Labor Economics 34(3): 663-704.

Farrell, Paul, and Alex McDonald. 2018. McDonald's accused of exploiting young workers with "learn and churn" practice." ABC News. Accessed at http:/www.abc.net.au/news/2018-1009/learn-and-churn-mcdonalds-accused-of-exploiting-young-workers/10342934? (October 9, 2018).

Flinn, Christopher. 2011. The Minimum Wage and Labor Market Outcomes. Cambridge, MA: MIT Press.

Giuliano, Laura. 2013. Minimum Wage effects on employment, substitution, and the teenage labor supply: Evidence from personnel data. Journal of Labor Economics 31(1): 155-94.

Hyslop and Stillman. 2007. Youth minimum wage reform and the labour market in New Zealand. Labour Economics 14(2): 201-230

Jacobson, Louis S., Robert J. LaLonde, and Daniel G. Sullivan. 1993. Earnings losses of displaced workers. American Economic Review 83(4): 685-709.

Katz, Lawrence F., and Alan B. Krueger. 1992. The effect of the minimum wage on the fast-food industry. Industrial and Labor Relations Review 46(1): 6-21.

Kreiner, Claus Thustrup, Daniel Reck, and Peer Ebbesen Skov. 2019. Do lower minimum wages for young workers raise their employment? Evidence from a Danish discontinuity. The Review of Economics and Statistics 
Manning, Alan. 2003. Monopsony in Motion. Princeton, NJ: Princeton University Press.

Neumark, David, and William Wascher. 2004. Minimum wages, labor market institutions, and youth employment: A cross-national analysis. Industrial and Labor Relations Review 57(2): $223-48$.

- 2007. Minimum wages and employment. Foundations and Trends ${ }^{\circledR}$ in Microeconomics 3(1-2): 1-182.

—2008. Minimum Wages. Cambridge, MA: MIT Press.

Nielsen, Helena Skyt, Torben Sørensen, and Christopher Taber. 2010. Estimating the effect of student aid on college enrollment: Evidence from a government grant policy reform. American Economic Journal: Economic Policy 2(2): 185-215.

Pereira, Sonia C. 2003. The impact of minimum wages on youth employment in Portugal. European Economic Review 47(2): 229-44.

Portugal, Pedro, and Ana Rute Cardoso. 2006. Disentangling the minimum wage puzzle: An analysis of worker accessions and separations. Journal of the European Economic Association 4(5): 988-1013.

Robinson, Joan V. 1933. The Economics of Imperfect Competition. London: Macmillan.

Sabia, Joseph J., Richard V. Burkhauser, and Benjamin Hansen. 2016. When good measurement goes wrong: New evidence that New York State's minimum wage reduced employment. ILR Review 69(2): 312-19.

Shannon, Michael. 2011. The employment effects of lower minimum wage rates for young workers: Canadian evidence. Industrial Relations: A Journal of Economy and Society 50(4): $629-55$.

Thompson, Jeffrey P. 2009. Using local labor market data to re-examine the employment effects of the minimum wage. Industrial and Labor Relations Review 62(3): 343-66.

Voortman, Linda, Sadet Karabulut, and Roos Vermeij. 2015. Alle (Jong) Volwassenen Gelijk Loon Voor Gelijk Werk. De Volkskrant. Accessed at https://www.volkskrant.nl/columnsopinie/alle-jong-volwassenen-gelijk-loon-voor-gelijk-werk b5779ea9/ (October 10, 2018). 
Yuen, Terence. 2003. The effect of minimum wages on youth employment in Canada: A panel study. Journal of Human Resources 38(3): 647-72.

Table 1. Summary Statistics of Youth Workers Aged 15 to 23

\begin{tabular}{lrr}
\hline Variable & Mean & \multicolumn{1}{c}{ SD } \\
\hline Age & 19.164 & 2.229 \\
Share of female workers & 0.497 & \\
Share of first-generation immigrants & 0.068 & \\
Share of second-generation immigrants & 0.144 & \\
Employment spell length (months) & 13.973 & 13.905 \\
Work intensity (share of FTE) & 0.465 & 0.302 \\
Annual gross earnings (in 1000€) & 6.674 & 8.348 \\
Gross hourly wage (in $€$ ) & 7.707 & 32.372 \\
\hline Observations & $9,175,212$ & \\
\hline
\end{tabular}

Notes: The data for Dutch population of workers aged 15 to 23, observed in years 2006 to 2012. Each observation represents a person-year record. Both earnings and wages are deflated to the 2006 levels. FTE, full-time equivalent; SD, standard deviation. 
Table 2. Estimation Results, Employment Duration Analysis

\begin{tabular}{|c|c|c|}
\hline Variables & Coefficients & $\mathrm{SE}$ \\
\hline $\log ($ duration $)$ & $0.576 * * *$ & $(0.0003)$ \\
\hline \multicolumn{3}{|l|}{ Proximity to birthdays } \\
\hline 6 months away & 1.000 & $(0.0021)$ \\
\hline 5 months away & 1.001 & $(0.0021)$ \\
\hline 4 months away & 1.000 & $(0.0021)$ \\
\hline 3 months away & 1.001 & $(0.0021)$ \\
\hline 2 months away & $1.006 * * *$ & $(0.0021)$ \\
\hline 1 months away & $1.015 * * *$ & $(0.0021)$ \\
\hline 0 months away & $1.011 * * *$ & $(0.0021)$ \\
\hline 11 months away & 0.999 & $(0.0021)$ \\
\hline 10 months away & 0.999 & $(0.0021)$ \\
\hline 9 months away & 1.000 & $(0.0021)$ \\
\hline 8 months away & 1.001 & $(0.0021)$ \\
\hline Age (below 17.5 years) & $1.942 * * *$ & $(0.0319)$ \\
\hline $\operatorname{Age}^{2}$ (below 17.5 years) & $0.997 * * *$ & $(0.0001)$ \\
\hline $\operatorname{Age}^{3}$ (below 17.5 years) & $1.000 * * *$ & $(0.0000)$ \\
\hline Age (at least 17.5 years) & $1.760 * * *$ & $(0.0223)$ \\
\hline $\mathrm{Age}^{2}$ (at least 17.5 years) & $0.998 * * *$ & $(0.0001)$ \\
\hline $\mathrm{Age}^{3}$ (at least 17.5 years) & $1.000 * * *$ & $(0.0000)$ \\
\hline \multicolumn{3}{|l|}{ Birth month } \\
\hline January & 1.001 & $(0.0021)$ \\
\hline February & $0.989 * * *$ & $(0.0021)$ \\
\hline March & $0.984 * * *$ & $(0.0021)$ \\
\hline April & $0.989 * * *$ & $(0.0021)$ \\
\hline May & $0.988 * * *$ & $(0.0021)$ \\
\hline June & $0.992 * * *$ & $(0.0021)$ \\
\hline July & 0.998 & $(0.0021)$ \\
\hline
\end{tabular}




$\begin{array}{lll}\text { August } & 0.992 * * * & (0.0021) \\ \text { September } & 0.992 * * * & (0.0021) \\ \text { October } & 0.992 * * * & (0.0021) \\ \text { November } & 0.995 * * & (0.0021)\end{array}$

\section{Calendar month}

$\begin{array}{lll}\text { January } & 0.666^{* * *} & (0.0014) \\ \text { February } & 0.583 * * * & (0.0013) \\ \text { March } & 0.601 * * * & (0.0013) \\ \text { April } & 0.608^{* * *} & (0.0013) \\ \text { May } & 0.659 * * * & (0.0014) \\ \text { June } & 0.762 * * * & (0.0015) \\ \text { July } & 0.893 * * * & (0.0017) \\ \text { August } & 1.200^{* * * *} & (0.0022) \\ \text { September } & 1.043 * * * & (0.0020) \\ \text { October } & 0.793 * * * & (0.0016) \\ \text { November } & 0.712 * * * & (0.0015)\end{array}$

\section{Calendar year}

\begin{tabular}{ccc}
2006 & $1.005^{* * *}$ & $(0.0015)$ \\
2007 & $1.106^{* * *}$ & $(0.0016)$ \\
2008 & $1.114^{* * *}$ & $(0.0016)$ \\
2009 & $1.057^{* * *}$ & $(0.0016)$ \\
2010 & $1.014^{* * *}$ & $(0.0016)$ \\
\hline Observations & $79.3 \mathrm{mil}$. \\
Log-likelihood & $-1.91 \times 10^{7}$
\end{tabular}

Notes: Results of the complementary log-log model of job separation risks. Coefficients are presented in the exponentiated form; coefficients greater than 1 denote a positive effect and coefficients lower than 1 denote a negative effect. Robust standard errors in parentheses. Data consist of monthly records of employment spells for Dutch population of workers aged 15 to 23, for years 2006 to 2011. SE, standard error.

$* * * p<0.01 ; * * p<0.05 ; * p<0.1$. 
Table 3. Estimation Results, RDD-RKD Model of Employment Levels

\begin{tabular}{lc}
\hline Variable & Coefficients \\
\hline$\gamma$ - change of the employment level (RDD) & $-0.318^{* * *}$ \\
$\delta$ - change of the employment slope (RKD) & $(0.024)$ \\
& $0.057^{* * *}$ \\
Age, centered at the discontinuity & $(0.017)$ \\
& $0.212^{* * *}$ \\
Age ${ }^{2}$, centered at the discontinuity & $(0.010)$ \\
& $-0.006^{* * *}$ \\
Constant & $(0.001)$ \\
& $52.974^{* * *}$ \\
\hline Number of observations & $(0.031)$ \\
\hline
\end{tabular}

Notes: Results of the limited dependent variable model of labor force participation. Coefficients are multiplied by 100 and presented as percentage point changes of the employment rate. Robust standard errors are adjusted accordingly and included in parentheses. Data consist of monthly labor force participation records of Dutch population in the 18-month intervals surrounding the 17 th and the 19th to 23rd birthdays, for years 2006 to 2011. RDD, regression discontinuity design; RKD, regression kink design

*** $p<0.01 ; * * p<0.05 ; * p<0.1$. 
Figure 1. Minimum Hourly Wage Rates in the Netherlands

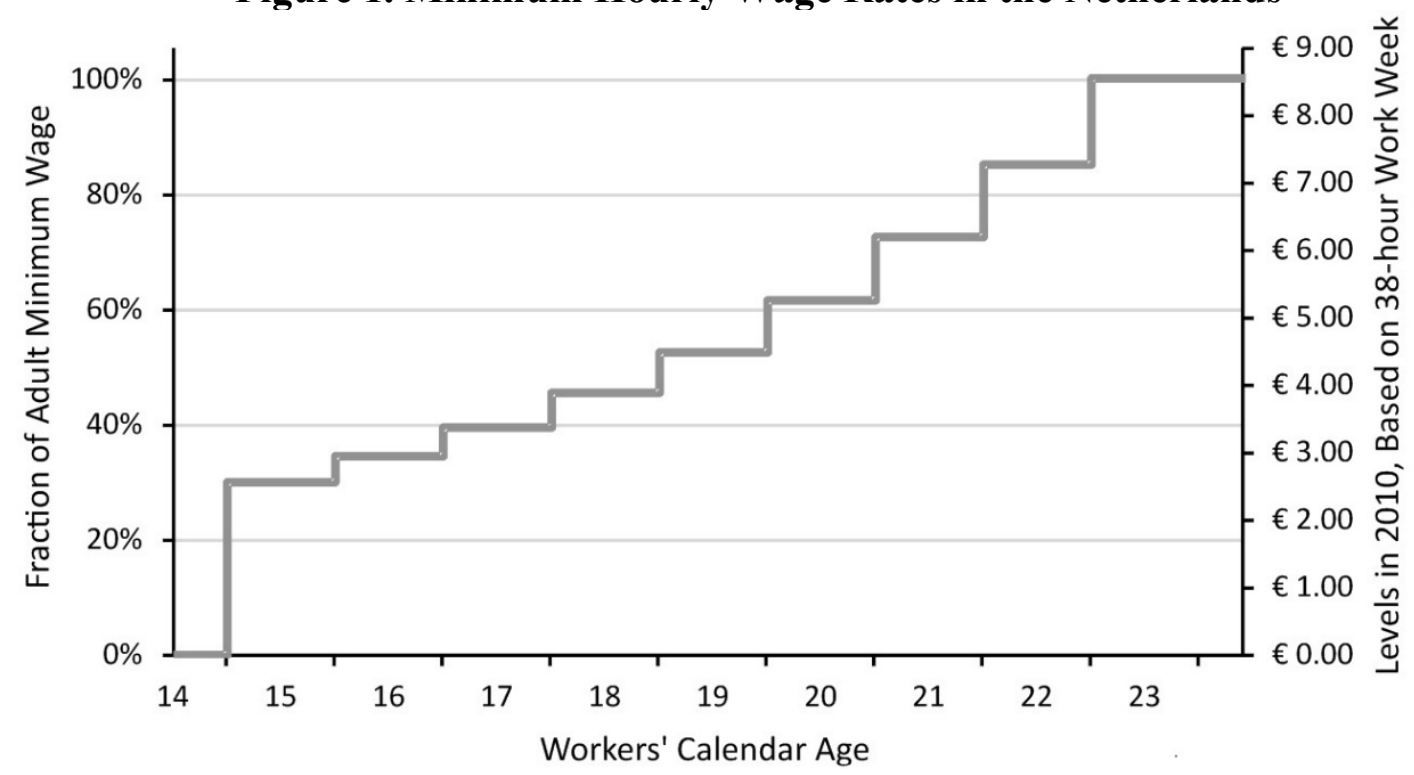

Source: Dutch Ministry of Social Affairs and Employment. 
Figure 2. Youth Employment Rate as a Function of Age

(a) Ages 13 to 25

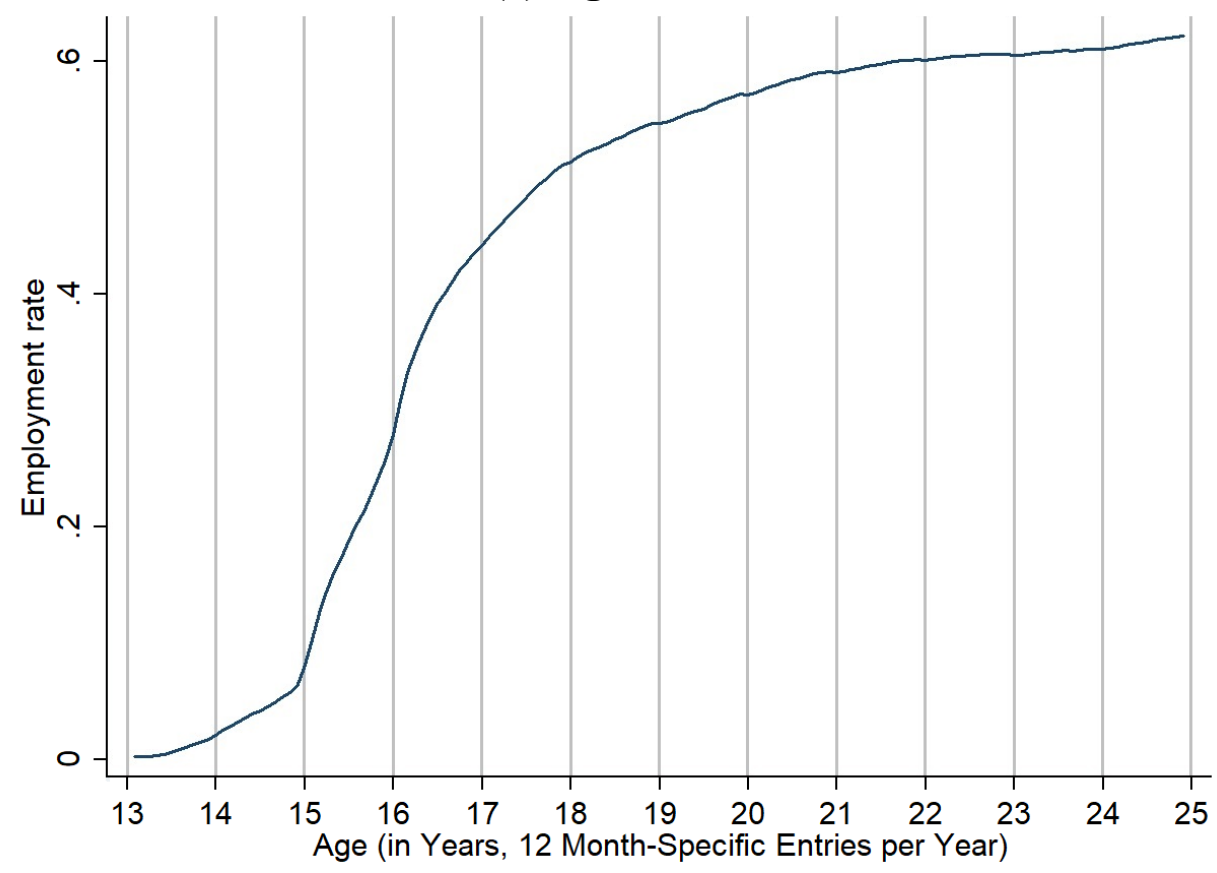

(b) Ages 18 to 25

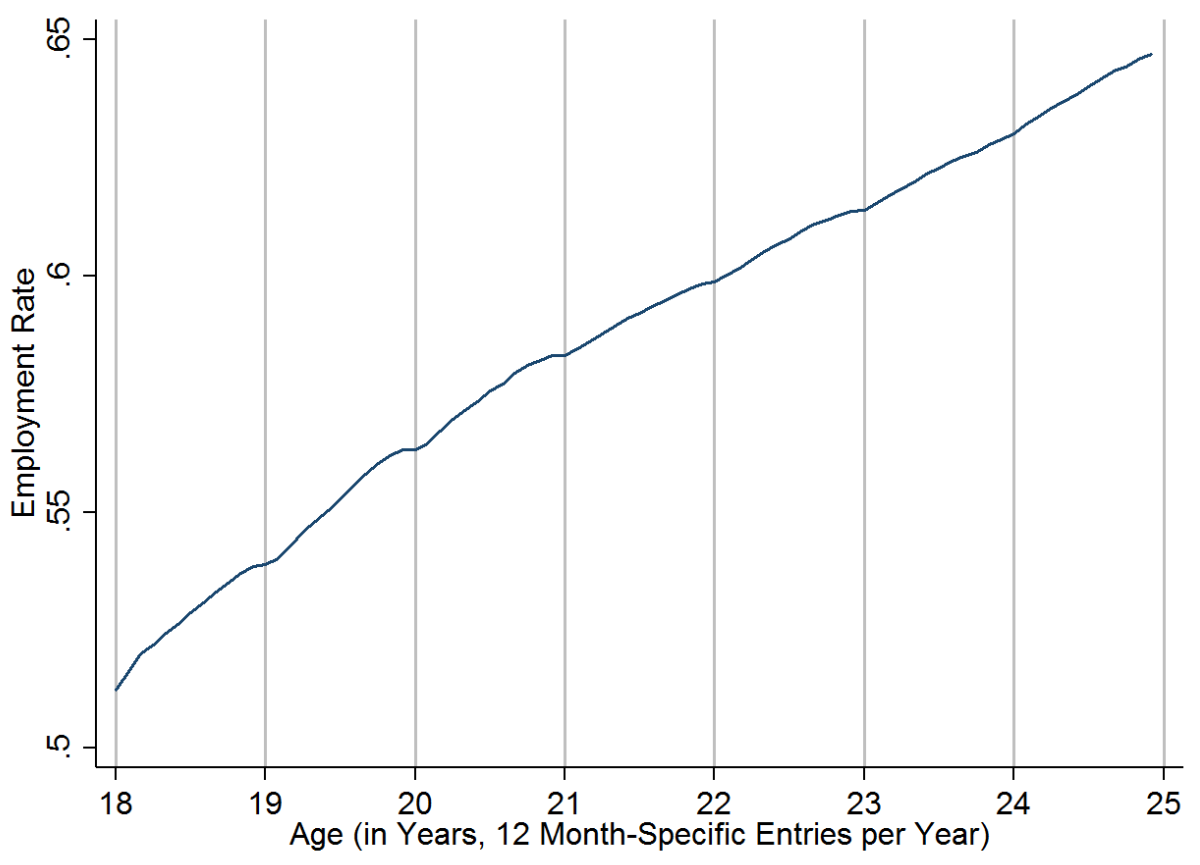

Notes: Employment rate indicates the share of working individuals in the population of given (monthly) age. Data for Dutch population aged 13 to 25, for years 2006 to 2012. 
Figure 3. Empirical Distribution and Average Levels of Gross Daily Wage

(a) Empirical distribution of gross hourly wages, relative to the minimum wage rate

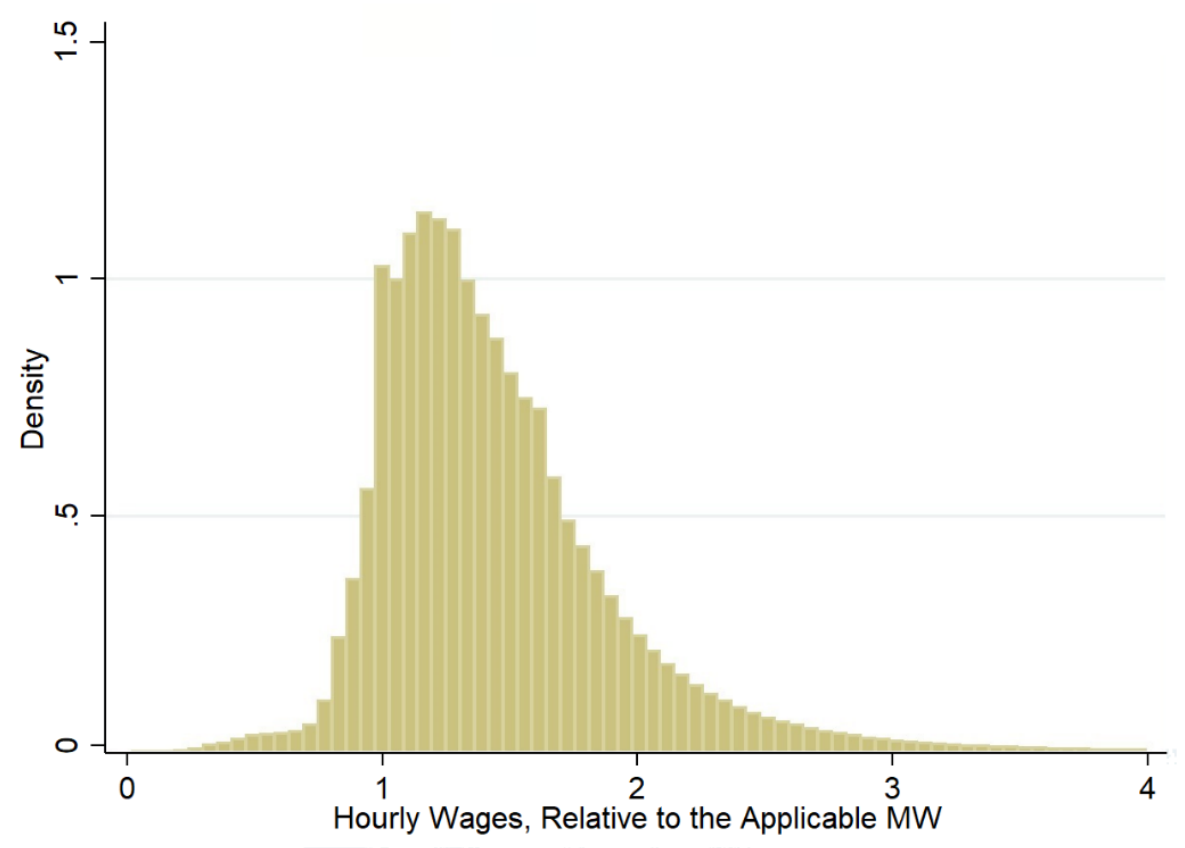

(b) Average levels of gross hourly wages, by workers' age and employment type

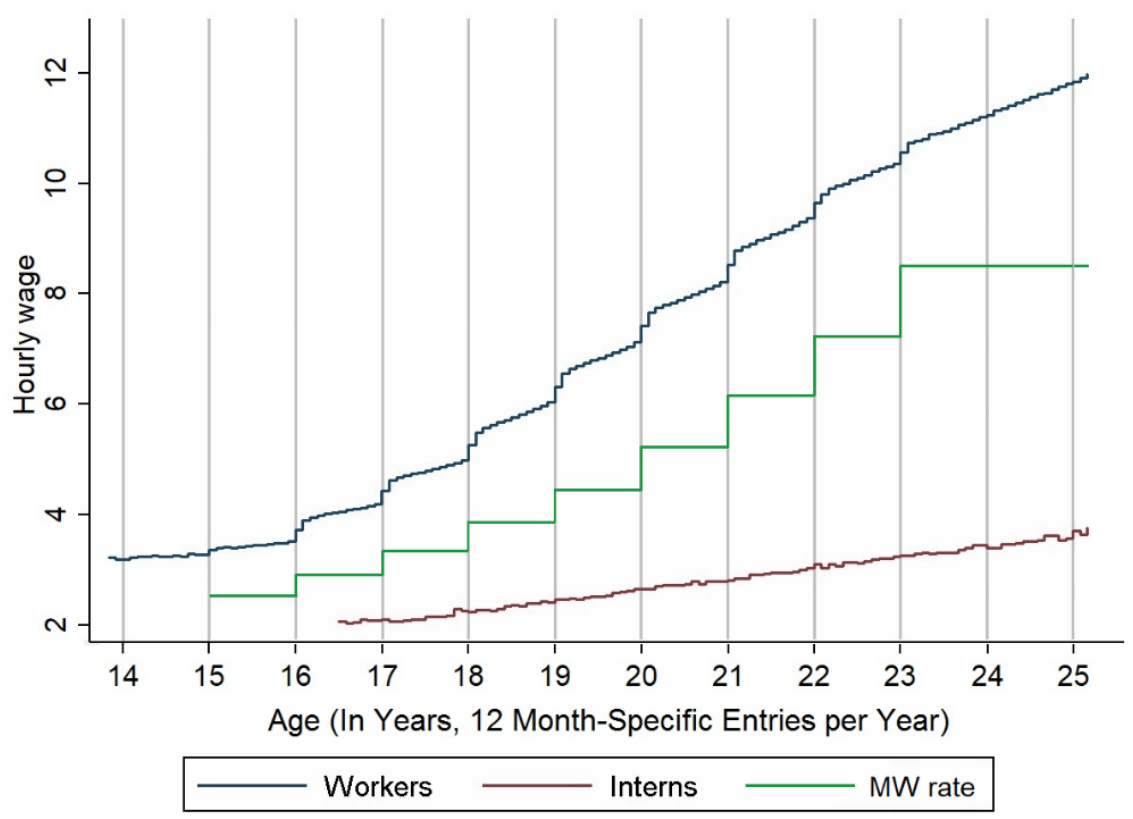

Notes: Panel (a) shows data for Dutch workers aged 15 to 23 who are not engaged in internships nor self-employed, for years 2006 to 2012. Panel (b) extends the age range to workers aged 14 to 25 and plots the hourly wages of workers engaged in internships separately. MW, minimum wage. 
Figure 4. Job Accession and Job Separation Frequencies as Functions of Workers' Age

(a) Job accessions

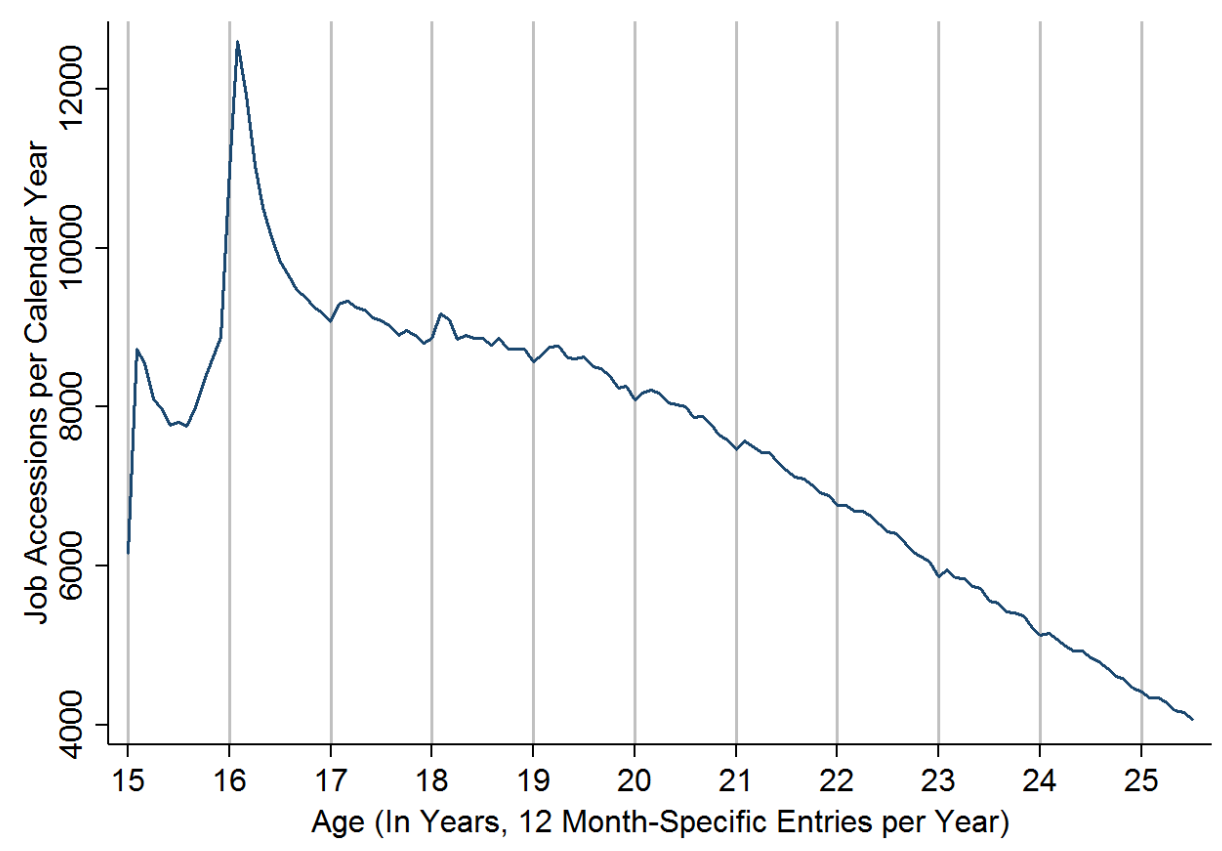

(b) Job separations

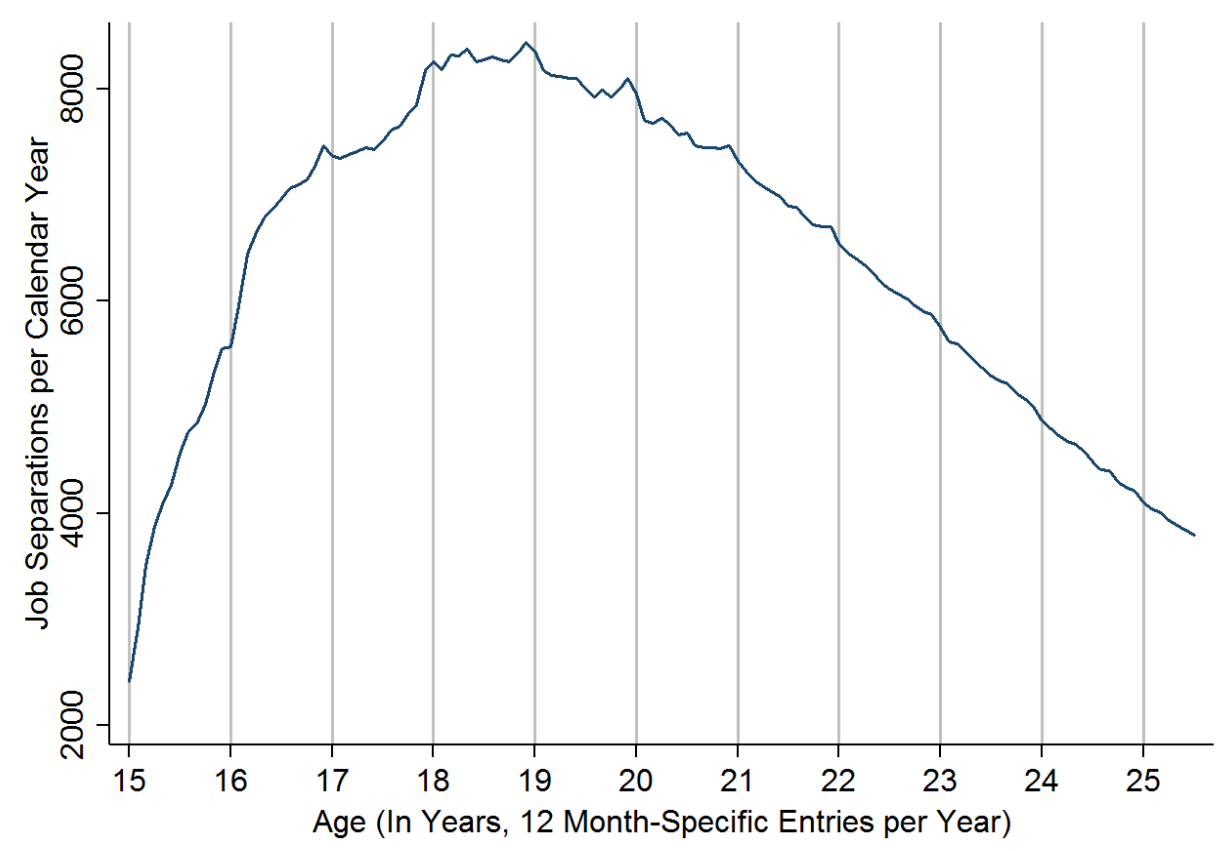

Notes: Data for Dutch population of workers aged 15 to 25, for years 2006 to 2012. 
Figure 5. Average Incidence of Job Accessions and Job Separations at Varying Proximities to Workers' Birthdays

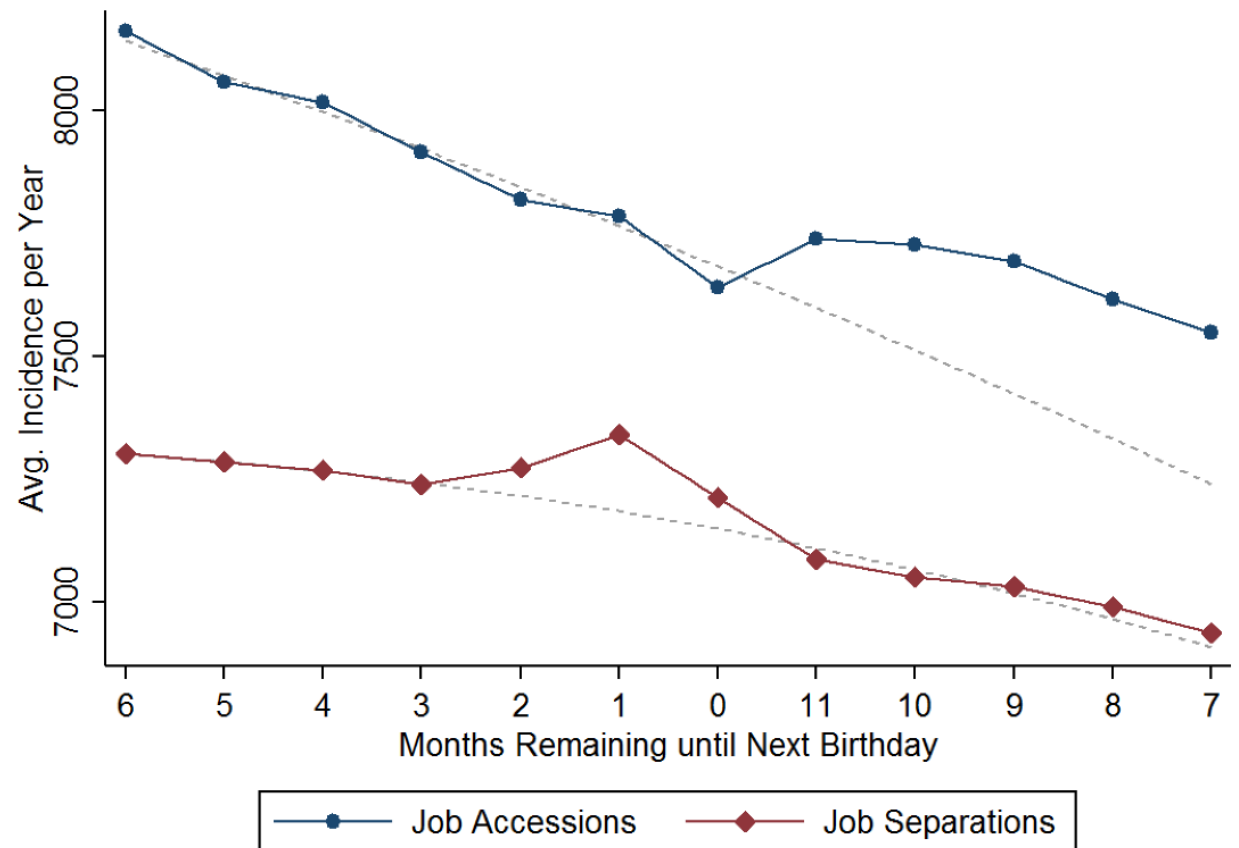

Notes: Pooled data for Dutch workers aged 17 and 19 to 23, for years 2006 to 2012. 
Figure 6. Predicted Changes of Job Separation Probability at Varying Proximities to Workers' Birthdays

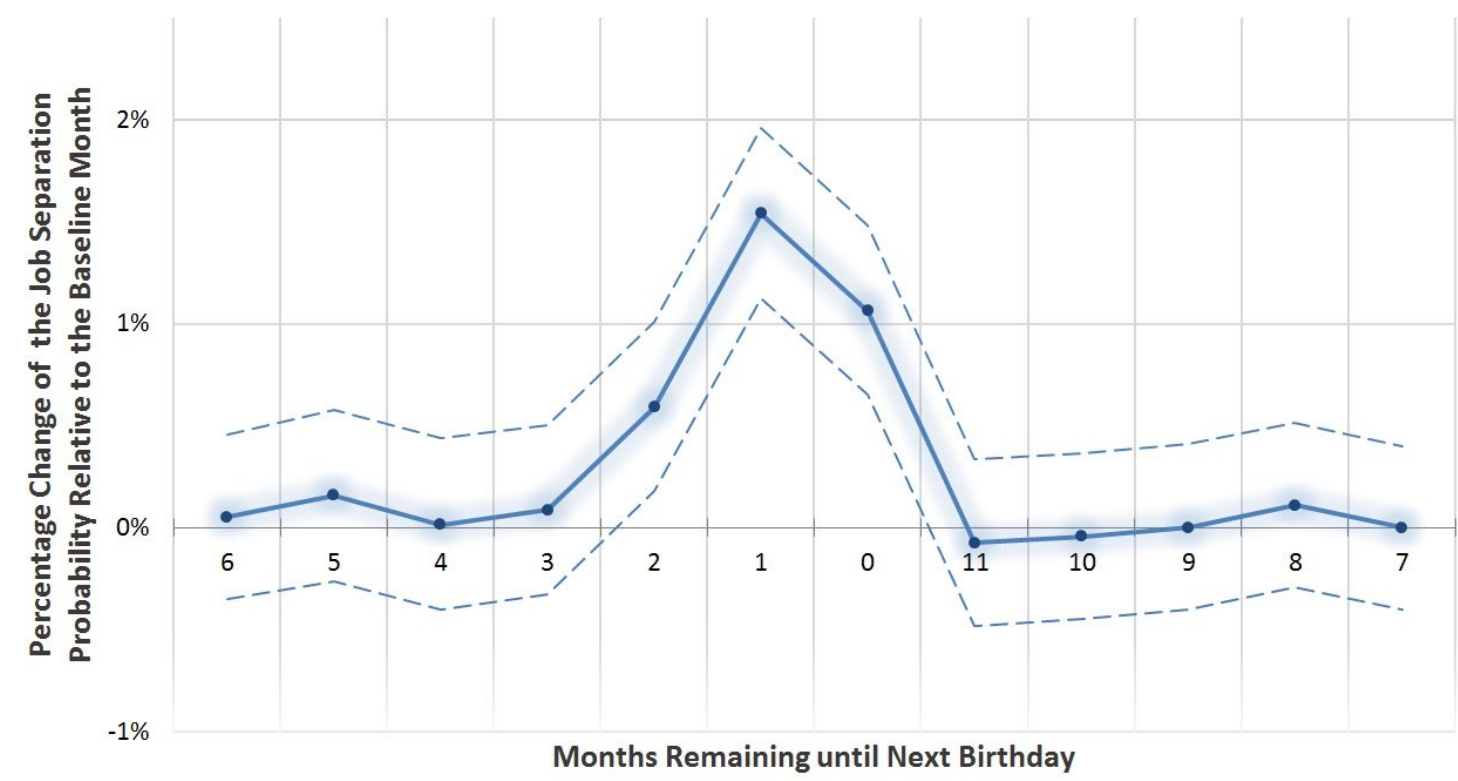

Notes: $m t b d$ dummy coefficients from the principal complementary log-log model of employment durations. Dashed lines indicate 95\% robust confidence intervals. Data for Dutch population of workers aged 15 to 23 , for years 2006 to 2011. 
Figure 7: Heterogeneity of the Birthday Effect

(a) With respect to a worker's age

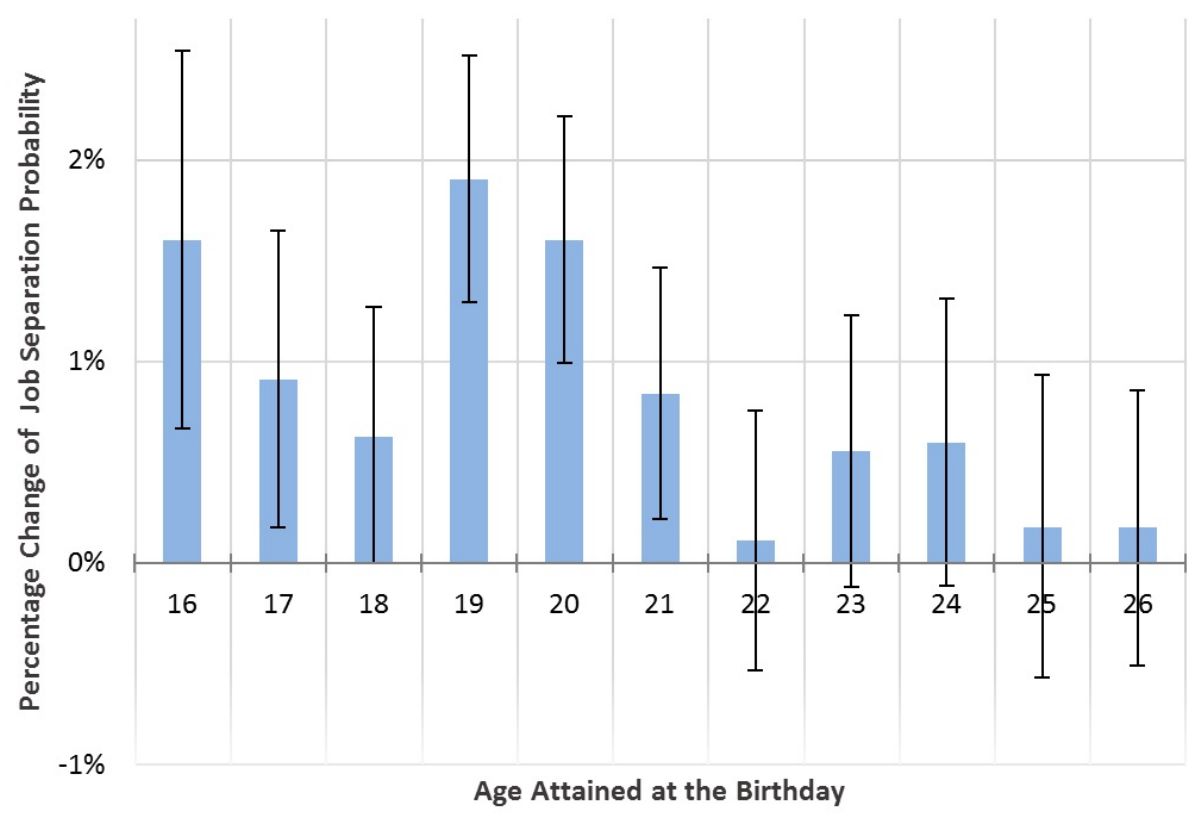

(b) With respect to calendar time

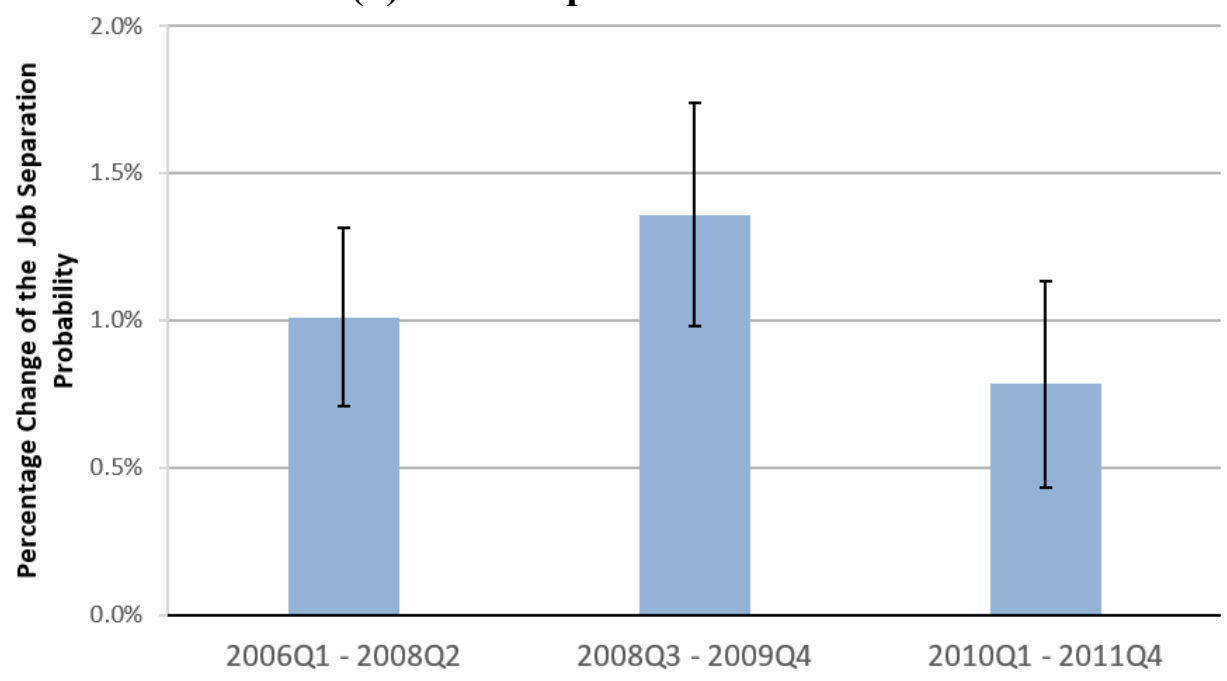


(c) with respect to employment sector

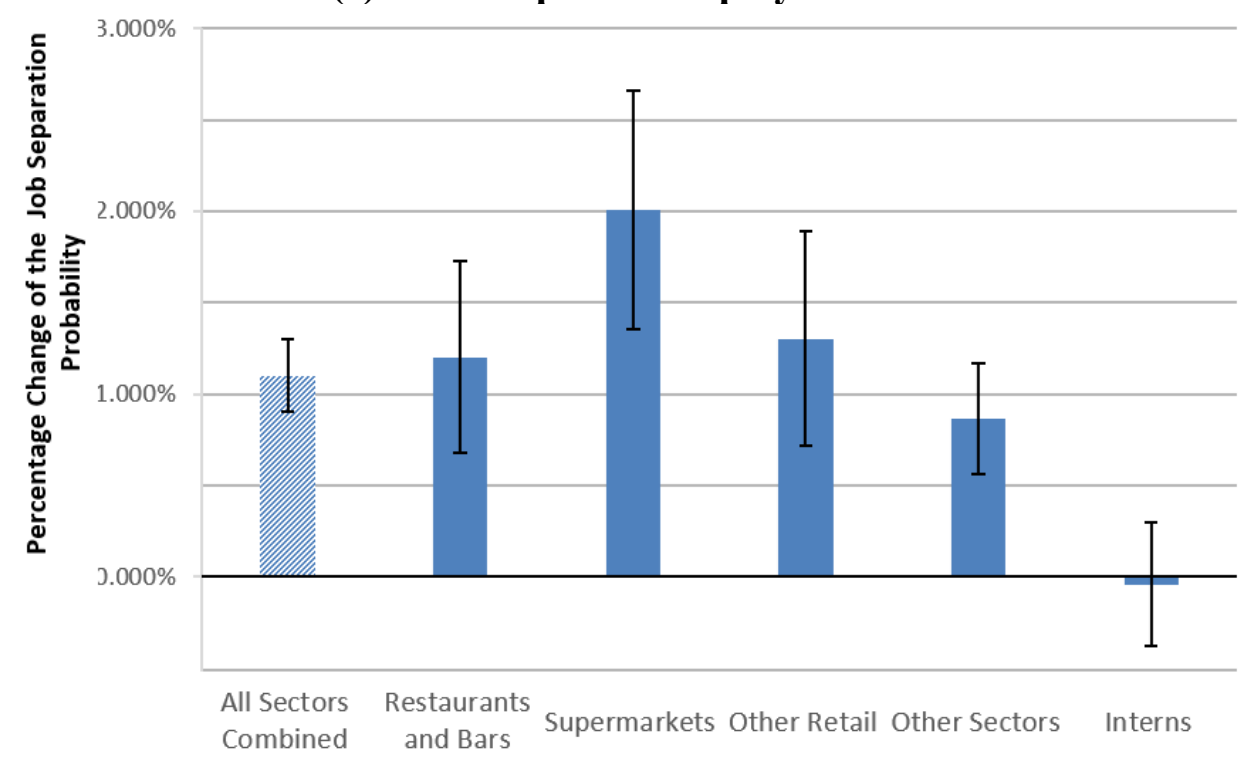

Notes: Bars indicate predicted changes of job separation probability in the three months closest to workers' next birthdays. Error bands represent $95 \%$ robust confidence intervals. Data for Dutch population of workers who are not self-employed, aged 15 to 23, for years 2006 to 2011. 
Figure 8. Relation between the Subgroup Effect Sizes and the Expected Bite of the Birthday Discontinuities

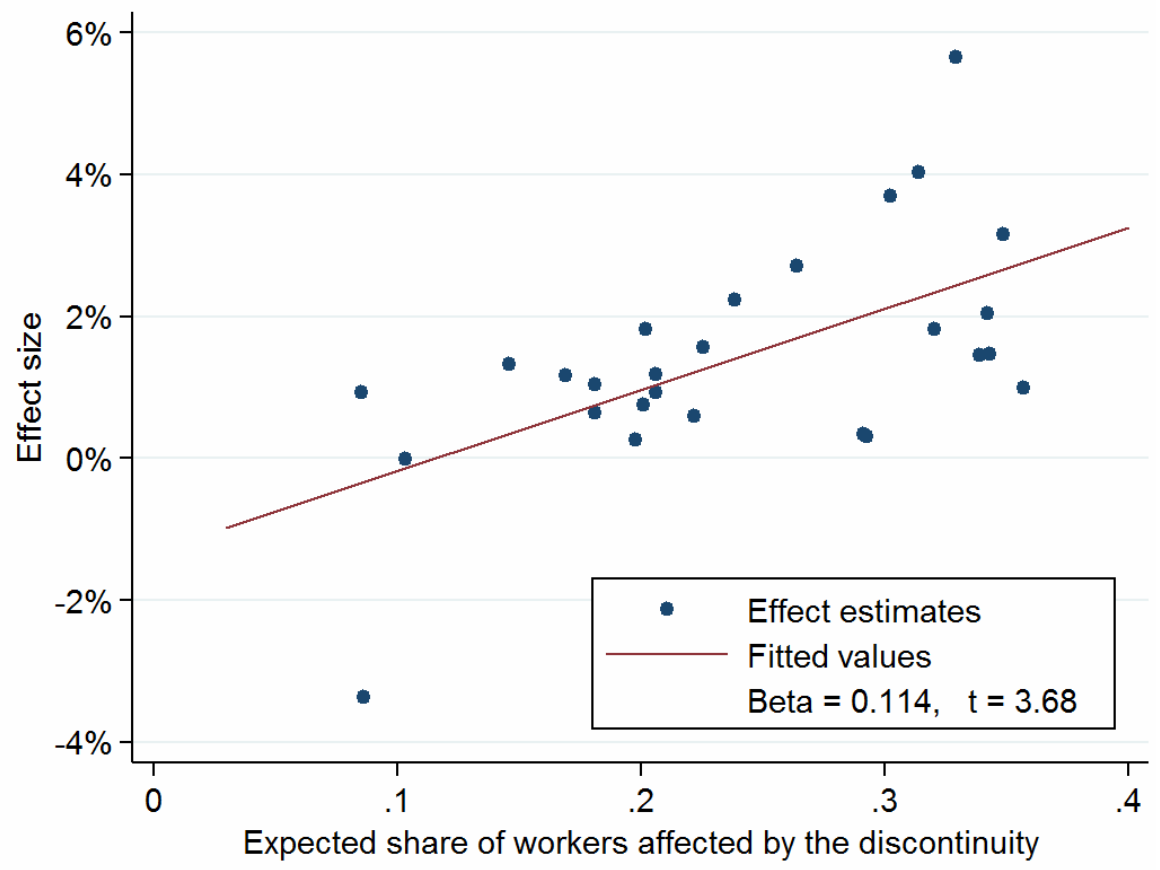

Notes: The $y$-axis indicates predicted changes of job separation probability in the three months closest to workers' next birthdays. The $x$-axis indicates the share of workers whose counterfactual wages grow slower than the age-dependent minimum wage rates. Workers are split into 27 subgroups based on their age, calendar time, and sector of employment. Data for Dutch population of workers not engaged in internships or self-employed, aged 15 to 23, for years 2006 to 2011 . 
Figure 9. Observed and Fitted Values of the Employment Rate near Birthday Discontinuities

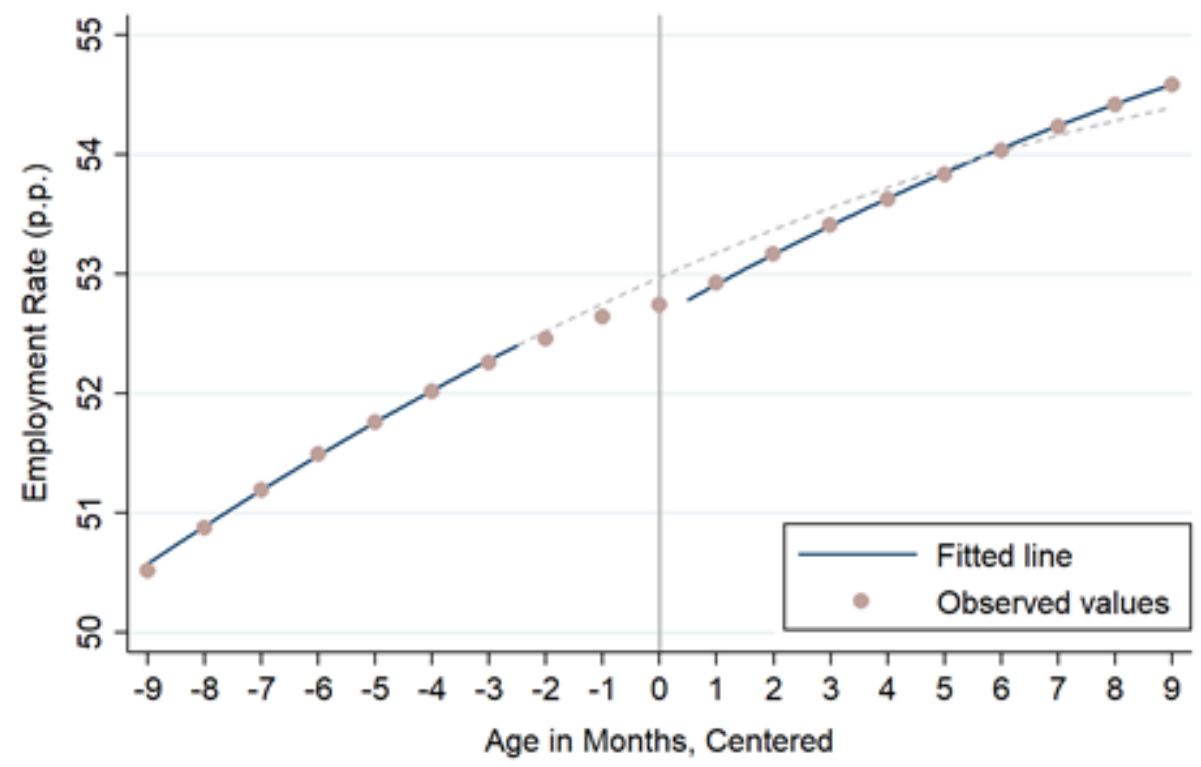

Notes: Dots denote observed values of the employment rate and the solid line represents fitted values from the RKD model with 18-month observation window. Dashed line illustrates the shape of the employment rate in the absence of RDD and RKD effects. Pooled data for Dutch population aged 17 and 19 to 23, for years 2006 to 2011. RDD, regression discontinuity design; $\mathrm{RKD}$, regression kink design. 


\section{University Library}

\section{- M M I N E R VA A gateway to Melbourne's research publications}

Minerva Access is the Institutional Repository of The University of Melbourne

Author/s:

Kabatek, J

Title:

Happy Birthday, You're Fired! Effects of an Age-Dependent Minimum Wage on Youth Employment Flows in the Netherlands

Date:

2020-01-21

\section{Citation:}

Kabatek, J. (2020). Happy Birthday, You're Fired! Effects of an Age-Dependent Minimum Wage on Youth Employment Flows in the Netherlands. ILR REVIEW, 74 (4), pp.1008-1035. https://doi.org/10.1177/0019793919897914.

Persistent Link:

http://hdl.handle.net/11343/267620 